University of Chicago Law School

Chicago Unbound

Journal Articles

Faculty Scholarship

1986

\title{
The Summary Jury Trial and Other Methods of Alternative Dispute Resolution: Some Cautionary Observations
}

Richard A. Posner

Follow this and additional works at: https://chicagounbound.uchicago.edu/journal_articles

Part of the Law Commons

\section{Recommended Citation}

Richard A. Posner, "The Summary Jury Trial and Other Methods of Alternative Dispute Resolution: Some Cautionary Observations," 53 University of Chicago Law Review 366 (1986).

This Article is brought to you for free and open access by the Faculty Scholarship at Chicago Unbound. It has been accepted for inclusion in Journal Articles by an authorized administrator of Chicago Unbound. For more information, please contact unbound@law.uchicago.edu. 


\title{
The Summary Jury Trial and Other Methods of Alternative Dispute Resolution: Some Cautionary Observations
}

\author{
Richard A. Posner $\dagger$
}

I have been asked to discuss alternatives to existing methods of judicial dispute resolution. The great interest in such alternatives reflects the widespread sense, which I share, ${ }^{1}$ that our courts are dangerously overloaded. I had originally planned to discuss a variety of alternatives, but as I explored the literature ${ }^{2}$ I became fascinated with the summary jury trial, and realized it was a subject worthy of an entire paper. But much of what I shall say about the summary jury trial applies to other alternatives as well, so that the paper is not quite so narrow as it may seem; and Part III discusses two of those alternatives.

\section{Criteria for Evaluation}

The criteria for evaluating proposed alternatives to the conventional methods of resolving legal disputes are mostly taken for

† Judge, U.S. Court of Appeals for the Seventh Circuit; Senior Lecturer, The University of Chicago Law School. This is a revised version of a paper given at the National Conference on Litigation Management at Yale Law School on October 4, 1985. The research assistance of Randal C. Picker is gratefully acknowledged, as are the comments of Picker, Albert Alschuler, Gregory Barton, Hugh Brenneman, Edward Brunet, Frank Easterbrook, E. Donald Elliott, Jerry Goldman, William Landes, John Langbein, Geoffrey Miller, Phil Neal, Anthony Partridge, Maurice Rosenberg, and Hans Zeisel on a previous draft of this paper; discussions of the subject-matter of the paper with Susan Getzendanner and Thomas Lambros; and comments of conference participants.

- See Richard A. Posner, The Federal Courts: Crisis and Reform pt. II (1985).

2 See, e.g., Elizabeth Rolph, Introducing Court-Annexed Arbitration: A PoliCYMaker's GutDe (Rand Inst. for Civ. Justice 1984); Alternatives to the High Cost of Litigation, Special Issue on Judicial ADR, 1985, passim (Center for Public Resources publication); Attacking Litigation Costs and Delay: Project Reports and Research Findings (Am. Bar Ass'n 1984); Symposium: Alternative Dispute Resolution, 29 VILL. L. REv. 1219 (1984); Bush, Dispute Resolution Alternatives and the Goals of Civil Justice: Jurisdictional Principles for Process Choice, 1984 WIs. L. Rev. 893; McMillan \& Siegel, Creating a Fast-Track Alternative Under the Federal Rules of Civil Procedure, 60 Notre Dame L. Rev. 431 (1985); Nejelski \& Zeldin, Court-Annexed Arbitration in the Federal Courts: The Philadelphia Story, 42 MD. L. Rev. 787 (1983); Peckham, A Judicial Response to the Costs of Litigation: Case Management, Two-Stage Discovery Planning and Alternative Dispute Resolution, 37 Rutgers L. REv. 253 (1985). 
granted. That is because those making the proposals are practical rather than theoretical men, and most practical men think they can tell at a glance whether something works, and if it does they pronounce it successful. I, however, a prisoner of my academic past, propose four stringent criteria for evaluating any procedural reform:

1. The procedure must conform to a model of rational litigant behavior. Although emotion and ignorance play a role in litigation, no proposed alternative is likely to work that assumes, implicitly or explicitly, that litigants and their lawyers are irrational. Rationality is the dominant although not the only characteristic of behavior in established institutional frameworks administered by professionals, such as that provided by the rules of federal trial procedure. I won't attempt to defend this premise in its full breadth but will note later some empirical support for the rational model of litigant behavior. ${ }^{3}$

2. The success or failure of the procedure must be verifiable by accepted methods of (social) scientific hypothesis testing. I am unconvinced by anecdotes, glowing testimonials, confident assertions, appeals to intuition. Lawyers, including judges and law professors, have been lazy about subjecting their hunches-which in honesty we should admit are often little better than prejudices-to systematic empirical testing. Judicial opinions and law review articles alike are full of assertions-about the effects of a comparative negligence standard, jurors' comprehension of instructions, the consequences of keeping religion out of (or putting it into) the public schools, the knowledgeability of consumers, the legal sophistication of prisoners, the social utility of pretrial discovery, the virtues of adversarial compared to inquisitorial techniques, and hundreds of other matters-that have no demonstrable factual basis. Not that the authors of these articles and opinions must be wrong on any of these assertions; they may be right on all. But they have only impressions; they have no verified knowledge. If we are to experiment with alternatives to trials, let us really experiment; let us propose testable hypotheses, and test them."

3 On rational theories of human behavior generally see, for example, GARY S. BECKRR, The Economic Approach to Human Brhavior (1976), and on their application to law see Richard A. Posner, The Economics of Justice ch. 1 (1981); Richard A. Posner, Economic ANALYSIS OP LAW chs. 1-2 (3d ed. 1986).

- On the application of social science methodology to law see, for example, Stigler, The Law and Economics of Public Policy: A Plea to the Scholars, 1 J. Legar Stud. 1 (1972); Zeisel, Reflections on Experimental Techniques in the Law, 2 J. LEGal STud. 107 (1973), 
3. Any alternative to the trial must respect relevant legal and institutional constraints, including those derived from the separation of powers in our constitutional system. This may seem a boring truism, but we shall see that there is a possibility that it is being contravened not only by the summary jury trial but by court-annexed arbitration.

4. Any proposed reform must move the legal system in the right direction, where "right" is defined in accordance with broad social policy rather than narrow craft standards of success. A proposal that reduced the cost of using the courts might, by increasing that use, disserve fundamental social interests-while serving all too well the legal profession's narrow self-interest.

\section{The Summary Jury Trial}

The summary jury trial was conceived by federal district judge Thomas Lambros. ${ }^{5}$ Although I shall raise questions about it, nothing I say should be taken as criticism of Judge Lambros, whose imagination has energized the field of procedural reform and given this paper its main subject.

\section{A. Description}

After pretrial discovery is completed and a pretrial conference held, a jury case that seems unlikely to settle on the eve of trial (as so many cases do) will be set for summary jury trial before a dis-

and, with specific reference to judicial administration, The ANaLYsis of Judicial REFoRM (P. DuBois ed. 1982); R. PosNER, supra note 1, pt. II, and studies cited therein; and the Landes and Danzon \& Lillard studies cited infra note 7. For an exemplary controlled experiment on the efficacy of a procedural reform, see Maurice Rosengerg, The Pretrial Conference and Effective Justice: A Controlled Test in Personal Injury Litigation (1964).

The empirical study of law is handicapped by the methods and organization of legal education, which are inhospitable to the methods and practitioners of social science. See $R$. PosNER, supra note 1, at 326-30. The characteristic hostility of law-trained persons for experimental studies of law is illustrated by EXPERIMENTATION IN THE LAW: REPORT OF THE Federal Judicial Center Advisory Committee on Experimentation in the Law (Fed. Judicial Center, Sept. 1981).

- See Lambros, The Summary Jury Trial and Other Alternative Methods of Dispute Resolution, 103 F.R.D. 461, 463 (1984). The appendices to Judge Lambros's report contain full descriptions of the procedure, including verdict forms and implementing local court rules. Id. at 480-518; see also M.-D. Jacoubovtch \& C. Moore, Summary Jury Trials in THE Northern District of OHIo (Fed. Judicial Center, May 1982). For briefer treatments of the summary jury trial see Lambros \& Shunk, The Summary Jury Trial, 29 CLEv. ST. L. REv. 43 (1980); Lambros, The Judge's Role in Fostering Voluntary Settlements, 29 VuL. L. REv. 1363, 1373-78 (1984), and for examples of the summary jury trial in action see Negin v. City of Mentor, 601 F. Supp. 1502, 1505 (N.D. Ohio 1985); Rocco Wine Distribs., Inc. v. Pleasant Valley Wine Co., 596 F. Supp. 617, 621 (N.D. Ohio 1984). 
trict judge or a magistrate. At the appointed time a jury is empaneled in much the usual manner, although in a summary jury trial the lawyers are not allowed as many challenges. The jurors are told it will be a summary jury trial but not-not yet anyway-that their decision will have no binding effect. ${ }^{6}$ The lawyers then present summaries of witness testimony plus their own argument. No live witnesses are called, but in summarizing the testimony that the witnesses would give if called the lawyers may not contradict any facts stipulated to or otherwise established in pretrial discovery. The jury is charged and deliberates, and returns a verdict in the usual way. The lawyers and their clients-for the parties themselves are required to attend the summary jury trial, the hope being that this will encourage settlement-can then talk to the jurors. The trial is intended to take the better part of a day, although I have been told of one that lasted six days.

The idea behind the summary jury trial is to facilitate settlement by giving parties and counsel a sense of how a jury is likely to evaluate their case. The verdict is in no way binding, and the parties can have a regular jury trial if they wish. But the summary jury trial is not voluntary; it is a compulsory part of the pretrial phase of the lawsuit, like a pretrial conference.

\section{B. Evaluation}

1. The Requirement of Rational Behavior. The summary jury trial does not flout my first criterion of evaluation; it does not rest on an assumption that litigants or their lawyers behave irrationally. If this seems rather a backhanded way of putting it, you will soon see why.

a. The Model of Settlement. Economists and economicsminded lawyers have modeled litigants' choice of whether to try or settle a case. ${ }^{7}$ The model predicts that the parties will settle if the plaintiff's minimum settlement price (demand) is less than the defendant's maximum settlement price (offer), or in symbols if

$$
P_{p} J-C+S<P_{d} J+C-S,
$$

\footnotetext{
- The practice on when, if ever, the jury is told its true function is not uniform. See infra notes 29-31 and accompanying text.

7 See, e.g., R. PoSNER, supra note 3, § 21.5, at 522-25; Landes, An Economic Analysis of the Courts, 14 J.L. \& Econ. 61 (1971); Shavell, Suit, Settlement, and Trial: A Theoretical Analysis Under Alternative Methods for the Allocation of Legal Costs, 11 J. Legal Stud. 55 (1982). Landes's article presents some empirical evidence supporting the economic model of litigation behavior, as does Danzon \& Lillard, Settlement Out of Court: The Disposition of Medical Malpractice Claims, 12 J. LEGAL STud. 345 (1983).
} 
or, equivalently, if

$$
\left(P_{p}-P_{d}\right) J<2(C-S) \text {. }
$$

$P_{p}$ is the probability of the plaintiff's victory as the plaintiff perceives it; $P_{d}$ the probability of the plaintiff's victory as the defendant perceives it; $J$ the judgment for the plaintiff if he wins; $C$ the cost of trial (assumed to be the same for both parties); and $S$ the cost of settlement (also assumed to be the same for both parties). The left side of inequality (1) is the plaintiff's minimum demand; the right side is the defendant's maximum offer. ${ }^{8}$

Admittedly the model is oversimplified. For example, it assumes that the parties' litigation and settlement costs are the same, that there are only two possible outcomes, $J$ and judgment for defendant (i.e., $J$ and zero), and that the parties agree on the value of $J$, though they may disagree about the probability that the plaintiff will win. But the complications one might introduce to make the model more realistic would not greatly affect the use I shall make of it; I shall illustrate this point in a moment.

Since we can assume that a trial costs more than a settlement, the value of $P_{p}-P_{d}$, the parenthetical term on the left side of inequality (2), is critical. If both parties are pessimistic, the parenthetical will be negative and the case will be settled. If, for example, the plaintiff thought he had only a .4 chance of winning but the defendant thought the plaintiff had a .7 chance of winning, both parties would want to settle because both would expect to lose if the case went to trial. Trial is more likely in the class of cases where both parties are optimistic, as where the plaintiff thinks he has a .9 chance of winning and the defendant thinks the plaintiff has only a .3 chance of winning. For example, given these probabilities, and assuming $J=\$ 10,000, C=\$ 2,000$, and $S=\$ 500$, the parties will litigate, since the plaintiff's minimum settlement price, $\$ 7,500$, exceeds the defendant's maximum settlement offer,

- $P_{p} J$ is the expected judgment to the plaintiff if he goes to trial, but is not his minimum settling price. His minimum settling price, or minimum demand, is the net expected benefit to him of going to trial, and so is lower than $P_{p} J$ by the difference between the plaintiff's trial and settlement costs (i.e., by $C-S$ ), since he will lose that difference if he goes to trial. Therefore the plaintiff's minimum demand is $P_{p} J-(C-S)=P_{p} J-C+$ $S$, the left side of inequality (1).

For the defendant, the excess of trial over settlement costs ( $C-S$ again), being an additional expected loss from trial, must be added to his estimate of the plaintiff's expected judgment $\left(P_{d} J\right)$ in determining a maximum settlement offer, i.e., the net amount the defendant expects to lose if the case is tried. Hence the defendant's maximum offer is $P_{d} J+$ $C-S$, the right side of inequality (1). 
$\$ 4,500$. Anything that reduces the gap in perceived probabilities will make settlement more likely unless it changes some other element in the model.

Professor Schuck's conference paper, which criticizes the settlement model that I have just sketched, ${ }^{\circ}$ is actually a case study in the application of the model. The costs of settlement $(S)$ in the case he discusses were very high because of the large number of parties. Other things being equal, a high $S$ will reduce the likelihood of a settlement (see inequality (2)). The district judge is depicted in Schuck's paper as reducing $S$ by injecting himself into the settlement process and by appointing settlement masters to assist in the negotiations. At the same time, the judge increased the costs of trial, $C$ (and with it the likelihood of settlement), by setting a very near trial date. Finally, he increased the convergence of the parties' estimates of the probable outcome at trial (i.e., reduced $P_{p}-P_{d}$ ) in two ways: (1) by indicating to the parties how he might rule on critical issues, and (2) by encouraging candid exchange of the parties' own estimates through the medium of the settlement masters. ${ }^{10}$

b. The Model Applied to the Summary Jury Trial. The summary jury trial reduces the gap between the parties' perceived probabilities of the outcome at trial by giving them information (in the form of the summary jury's reactions to the case) that should cause them to adjust their perceptions. Because the information is available to both parties, it should help each to get closer to the true odds, which will usually be somewhere in between the parties' estimates. The summary jury trial may also help the parties converge in their estimates of the size of the judgment if the case goes to trial. Although my formal model assumed away any possible divergence in these estimates, it is of course very common for the plaintiff not only to be more optimistic about the outcome than the defendant thinks warranted, but to expect a larger judgment (if judgment is for the plaintiff) than the defendant expects to lose. Narrowing this divergence will make a settlement more likely.

- Schuck, The Role of Judges in Settling Cases: The Agent Orange Example, 53 U. CHI. L. Rev. 337, 339-40, 353 (1986).

10 The lawyers for opposing parties in litigation are often unwilling to "level" with each other, hoping to obtain tactical advantages from surprise. Apparently they were more forthcoming with the settlement masters, who were not interested in obtaining tactical advantages for their clients since their only client was the judge. The literature on game theory provides support for the use of such mediators to promote the settlement of disputes. See Roger B. Myerson, ANalysis of Incentives in Dispute Resolution (Northwestern U. Graduate Sch. of Mgmt., Oct. 1985). 
True, the parties could always arrange for a mock summary jury trial on their own-in much the same way that lawyers preparing for jury trials in big cases will sometimes hire mock juries to hone their forensic skills on. But real and mock summary jury trial would differ in two respects. First, while a mock jury is a mock jury, the jury in a summary jury trial is a real jury which (usually) doesn't know until too late, as it were, that it is rendering a merely advisory verdict. Every jury-trial lawyer and judge knows (or thinks he knows) that jurors take seriously the reiterated admonitions that they are deciding a matter of consequence and endeavor conscientiously to discharge this duty of citizenship. But about the conscientiousness of mock juries and therefore their comparability to real juries there is a nagging doubt. ${ }^{11}$

Another difference between the mock jury and the summary jury is that the government pays the latter (at the same rate as regular federal jurors) and, with its power of conscription, pays what for many of them is a below-market wage. Thus the saving to the litigants from not having to pay for this settlement aid at market rates is even greater than the government's actual budgetary cost. $^{12}$ Can a public subsidy of the settlement process be justified? In this age of swollen caseloads, maybe it can be. The benefits of settlement go not only to the parties but to other users of the court system, who face shorter queues and less harried judges as the settlement rate rises. Since parties who settle create external benefits, maybe they should be allowed to create some offsetting external costs, too; ${ }^{13}$ maybe that will bring us closer to the socially optimum level of settlements. This is especially plausible because the government subsidizes litigation. Since the parties bear only a fraction of the costs they impose on the judicial system and other litigants, an offsetting or even greater subsidy to settlement may be warranted. ${ }^{14}$

11 In R. Hastie, S. Penrod \& N. Pennington, Inside the Jury ch. 3 (1983), however, the authors argue forcefully that experiments using mock juries can be made sufficiently realistic to yield reliable predictions about the behavior of real juries.

12 This is a private rather than social saving. The real costs of the jury are no lower than if jurors were paid a market wage, but with conscription much of the cost is borne by the jurors themselves.

13 This is a standard technique in law. See, for example, the doctrines of "public necessity" and of "economic loss" in tort law, discussed in Richard A. Posner, Tort Law: Cases aNd Economic ANALysis 186-87, 467-68 (1982).

34 The existence of a positive externality may also explain why the summary jury trial must be compulsory, instead of the parties' being allowed to decide whether to have one. The private costs of this technique might exceed its private benefits and yet be lower than the social benefits. Also, judges who use summary jury trials may not fully trust lawyers to 
The noncommittal manner in which $I$ have put the case for subsidizing settlement is deliberate. Settling a case may also require an expenditure of judicial resources; the summary jury trial itself illustrates this point. Reducing (by subsidizing) the litigants' costs of settling cases might, by reducing the cost of resorting to the courts in the first place, actually increase the total costs of the system, even if the settlement rate rose. I shall come back to this issue later.

Moreover, although the summary jury trial does seem likely to reduce the uncertainty that the economic model (as well as common sense) predicts is a big factor in the decision to try rather than settle a case, it does not follow that the settlement rate will rise. Uncertainty is not the only variable in the model. The summary jury trial may also alter trial costs and (as already suggested) settlement costs, and in the model the difference between the two $(C-S)$ is also critical to the decision whether to go to trial.

The direction in which summary jury trial alters trial and settlement costs, however, is a question of some difficulty. If one evaluates these costs as of the end of the procedure, then it seems that summary jury trial reduces both types of cost, though probably only slightly. It reduces litigation costs by giving the parties a realistic and partly government-financed rehearsal that substitutes for a part of their trial preparation. It reduces settlement costs by providing a forum, again partly government-financed, for settlement negotiations. It does these things because, as we have seen, it is a free (and superior) substitute for information the costs of which would have been borne entirely by the parties. ${ }^{15}$ If trial and settlement costs are reduced by the same percentage, the absolute difference between them must shrink; for example, if $C$ falls by 25 percent, from $\$ 1,000$ to $\$ 750$, and $S$ also by 25 percent but from $\$ 600$ to $\$ 450$, the difference between $C$ and $S$ will fall from $\$ 400$ to $\$ 300$. Therefore the likelihood of trial must increase. This effect would have to be balanced against that of increasing the convergence of the parties' estimates of their chances at trial.

But the end of the summary jury trial is not the right point at which to measure trial and settlement costs. The right point is whenever settlement negotiations do or could occur. And until the summary jury trial takes place, its cost to the parties enters into their decision calculus as a cost of continuing to litigate rather

be the loyal and effective agents of their clients.

${ }^{15}$ Setting to one side other forms of judicial involvement in settlement. See, e.g., supra text accompanying note 9 . 
than settling before the summary jury trial. Hence $C$ will increase relative to $S$ and make settlement more likely, quite apart from (and in addition to) the fact that the probability of settlement will rise because uncertainty about the outcome at trial is reduced and $C$ and $S$ are (by assumption) unchanged.

Hence the summary jury trial should, as its advocates contend, increase the likelihood of settlement, ${ }^{16}$ though the effect may not be great because the reduction in uncertainty brought about by the summary jury trial may not be great:

(1) The jury's principal function is to determine the credibility of witnesses, yet there are no witnesses in the summary jury trial. The credibility assessed is that of the lawyers. A jury may react quite differently when confronted with the actual witnesses. We do not need a jury of laymen to decide which of two lawyers is more credible.

(2) If there is substantial variance in verdicts among different juries deciding the same case, the verdict in the summary jury trial will convey only limited information about the likely verdict of the real jury that will hear the case if the parties do not settle; so the gap between $P_{p}$ and $P_{d}$ will shrink only slightly.

(3) As lawyers become more experienced in conducting summary jury trials, we may see more "strategizing"-lawyers holding back some of their best evidence or arguments in an effort to surprise the opponent at the real trial, should the summary jury trial not lead to settlement.

Maybe a summary bench trial, which would avoid problems (1) and (2) as well as some of the legal problems discussed later, deserves consideration as an alternative device for facilitating settlement.

2. Verifiability of Effects. My second criterion for a proposed alternative to the conventional trial was that its effects be verifiable. This ideally would require that cases be assigned randomly for summary jury trial, with other cases receiving the usual treatment. And by random, I mean random; I mean by use of a table of random numbers. Then the summary jury trial cases could be compared with a proper control group and, provided there were enough cases in each group to allow statistical comparison, we would know whether there were any differences and, if so, what they were. ${ }^{17}$

\footnotetext{
${ }^{16}$ Increase it over what? is a very important question, however, to which I shall return. See infra text accompanying note 23 .

17 For noteworthy examples of the statistical study of a procedural device see Rosenberg's 1964 study of pretrial conferences, supra note 4, and Zeisel \& Callahan, Split Trials
} 
The qualification is critical, since if there are only a few cases in each group we can have no assurance that the groups are comparable. But it would not be difficult to obtain a large enough sample. There are more than 14,000 civil trials in the federal courts each year, ${ }^{18}$ and a much larger number of cases that are set for trial, since many cases settle on the eve of trial. If for just one or two years one percent of the cases ready for trial were assigned randomly for summary jury trial, we would have an adequate sample for purposes of statistical study.

No such study has been attempted. Judges who like the idea of the summary jury trial use it in cases they think will benefit from it. Neither the presiding judge nor the case is chosen randomly. So the fact that many judges who use the summary jury trial are enthusiastic about it may tell us little about its effectiveness.

A simpler but inferior alternative to a randomized study would be for judges conducting summary jury trials to record certain information: (1) the parties' estimates of how long the real trial would take, (2) the length of the summary jury trial, (3) whether the case was settled or, if not, (4) the length of the real trial. The problem with this method is that the cases settled after summary jury trial might have been settled by another, maybe cheaper, form of judicial intervention. (In contrast, if a control group were used, the effectiveness of any settlement devices used in lieu of summary jury trials would be tested automatically.) Nevertheless the method would at least yield information on the maximum benefits realistically to be expected from the use of summary jury trials.

A third possibility would be to require the lawyers in a summary jury trial to submit anonymous evaluations of the procedure to the Federal Judicial Center. Anonymity would prevent the lawyers from trying to curry favor with the judge by praising the procedure (chosen by the judge) or its implementation (by the judge). If the plaintiff's and the defendant's lawyers disagree in their evaluation, I would be inclined to discard it; winning or losing a case can distort perceptions severely. But if both lawyers concur in ei-

and Time Saving: A Statistical Analysis, 76 Harv. L. Rev. 1606 (1963). The dates of these two studies show that the statistical study of legal procedure is not just a fad of the 1980s. And, of course, such studies have long been standard in the evaluation of new medical procedures.

is See Administrative Office of the U.S. Courts, 1985 Annual Report of the DirecTor table C8. 
ther a positive or negative evaluation, I would consider it pretty reliable. ${ }^{19}$

The failure to use scientific methods to evaluate the summary jury trial can be compared instructively with the method being used to evaluate the experimental federal prison at Butner, North Carolina, a prison designed (penologically, not architecturally) by my distinguished academic colleague, Norval Morris. Butner is a prison largely without bars. Prisoners live in unlocked rooms rather than cells and are allowed to wear their street clothes. Guards do not wear uniforms. Thus, an effort is made to create as noncoercive an atmosphere as possible, coupled, however, with the insistence that the prisoners use their time productively.

If the people running Butner were allowed to choose the prisoners, the experiment would be pronounced an astonishing success. Professor Morris was not interested in such facile triumphs, and insisted that a certain number of prisoners be assigned randomly and that their behavior in Butner and after release be compared with a control group of inmates of other federal prisons. ${ }^{20}$ The experiment has been going on for eight years and has revealed that (1) Butner's alumni have the identical recidivism rate as the control group, but (2) the level of prison violence among Butner's inmates is only half that of the control group. These statistics provide a solid basis for pronouncing Butner a substantial though limited success-though unfortunately the imitation by other federal prisons of some of the experimental features of Butner may have contaminated the control group to some extent.

I anticipate the objection that lawsuits are less fungible than prisoners. Whether true or not, this is not a valid objection to my suggested procedure. If one picked 1,000 federal civil cases at random, divided them randomly into two groups of 500 cases each, used summary jury trial in each case in one group but in no case in the other group, and then found that the settlement rates in the two groups differed substantially, it would be hard to argue that summary jury trial had made no difference. There would be many differences among the cases in both groups, but with each group being both large and randomly selected, all the differences but

19 In M.-D. JACOUBOVITCH \& C. MoORE, supra note 5, at 7-20, the authors present results of a questionnaire sent to lawyers who had participated in summary jury trials. The responses were generally favorable to the device, but no effort was made to confine analysis to cases in which both the plaintiff's and the defendant's lawyers concurred in the evaluation.

${ }^{20}$ See Norval Morris, The Future of Imprisonment 117-21 (1974). 
one-the use or nonuse of summary jury trials-would tend to cancel out, thus isolating the effect of summary jury trial.

In lieu of an experiment I have done some very crude number crunching in an attempt to see whether the summary jury trial has made any difference in Judge Lambros's own district, the Northern District of Ohio. Using published statistics of the Administrative Office of the U.S. Courts for the five years before and the five years since Judge Lambros introduced the device, ${ }^{21} \mathrm{I}$ compared various indicia of judicial performance in his district with the other district in Ohio and with all other districts in Judge Lambros's circuit, the Sixth Circuit (that is, with all Sixth Circuit districts except the Northern District of Ohio).

Table 1

Active Summary Jury Trial Districts

District Number of SJT's

By \% of Cases

N.D. Ohio

D. Mass.

W.D. Mich.

100

$1.80 \%$

W.D. Okla.

69

$1.49 \%$

S.D. Ohio

36

$1.39 \%$

13

$0.40 \%$

E.D. Penn.

S.D. Fla.

10

$0.16 \%$

E.D. Mich.

7

$0.10 \%$

5

$0.09 \%$

M.D. Penn.

3

$0.04 \%$

3

$0.15 \%$

My study is admittedly very crude and, among other things, ignores the fact that there are nine other judges in the Northern District. Nevertheless, the device appears to be used much more frequently there than in any other district in the Sixth Circuit. Table 1 (compiled from correspondence with judges known or believed to have used the device), which estimates the number of summary jury trials conducted since 1980 , by district, shows that the device is used ten times as often in the Northern as in the Southern District of Ohio, and rarely, if ever, elsewhere in the Sixth Circuit. Of course, even in the Northern District of Ohio it is used in only a small number of cases, and this limits its possible impact. But since trials are not all of the same length, a settlement device that eliminated long trials (as summary jury trial is alleged

23 He introduced the device in March, 1980, shortly before the beginning of the 1981 judicial year on July 1, 1980. 


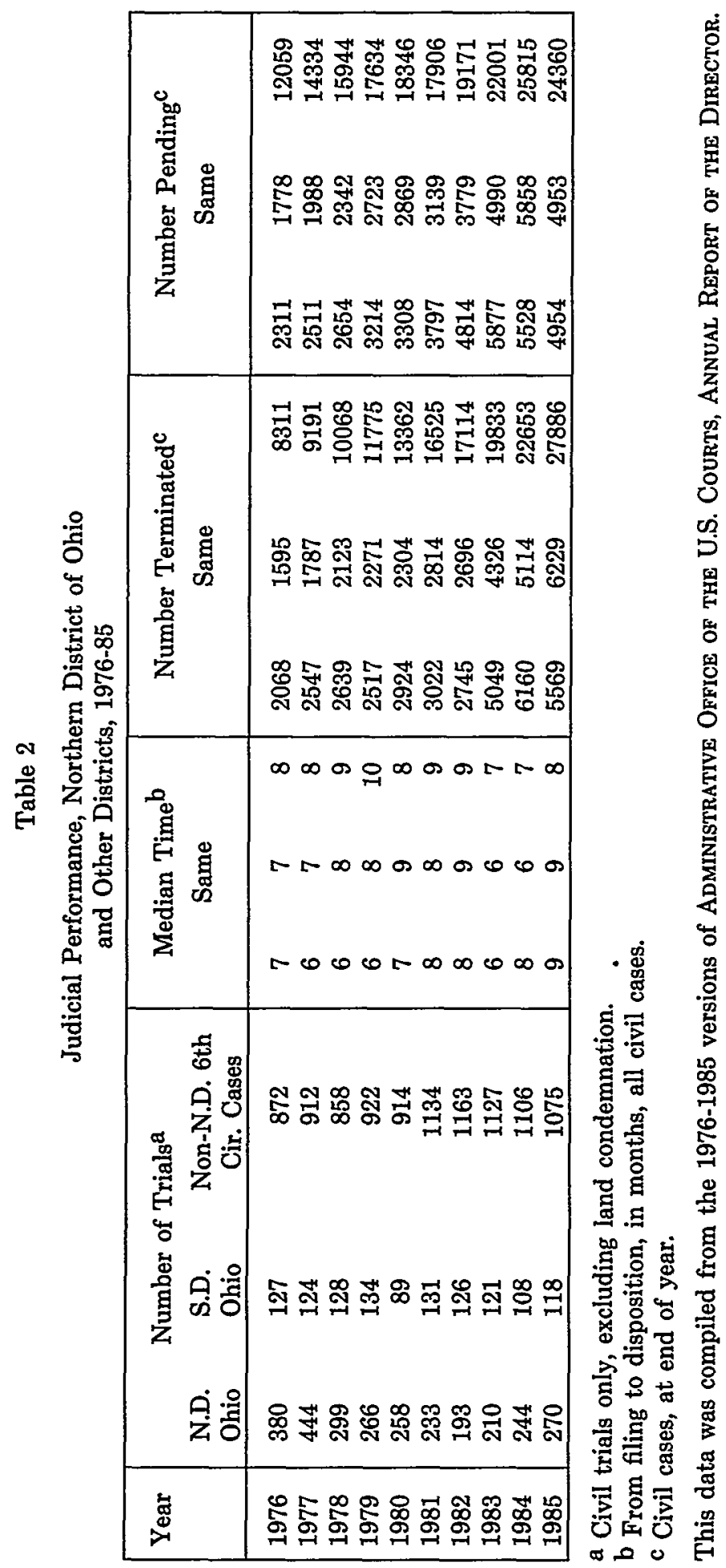


to do) might have effects disproportionate to the number of cases in which it was used.

Table 2 summarizes the study's results. A simple comparison of the number of trials might suggest dramatic improvements in the Northern District. Civil trials in the Northern District declined in number from 380 to 270 , compared to a much smaller decline in the Southern District and an increase for the circuit as a whole. But as shown graphically in Figure 1, this decline began years before the summary jury trial was introduced and leveled off after its introduction-the opposite of what one would expect if the device raises the settlement rate. This is not conclusive evidence against the efficacy of summary jury trials, since (among other things) extraneous forces may have been pushing up the number of trials and the summary jury trial may have held these forces in check. A simple comparison with the trend in the number of trials in non-Northern District (NND) districts (the top line in Figure 1) would so suggest. But comparison with the Southern District (the bottom line) suggests not.

Figure 1

Number of Trials

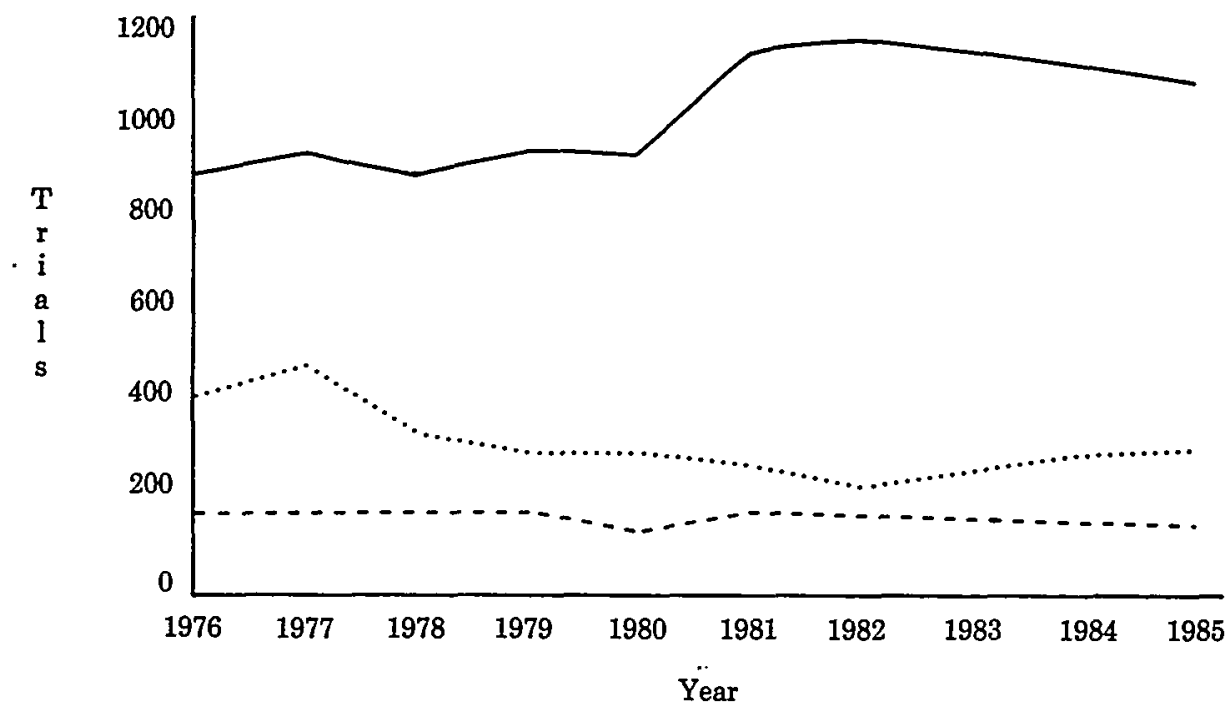

N....... Number of Trials, N.D. Ohio

- - - - Number of Trials, S.D. Ohio

Number of Trials, 6th Cir., Non-N.D. Ohio

Looking now to median disposition time, one finds no significant trend, but again the Northern District's performance is not 
particularly impressive. In the five years before the summary jury trial was introduced, the average time from filing to disposition of a civil case in the Northern District was 6.4 months, compared to 7.8 months for the Southern District and 8.6 for the NND districts. For the five "after" years the figures are 7.8, 7.6, and 8-higher for the Northern District, lower for the Southern District and for the NND districts. ${ }^{22}$ This is the opposite of what advocates of summary jury trials would predict.

The data on number of cases terminated and number of cases pending provide further indicators of efficiency in the disposition of judicial business. In the five "before" years, the Northern District terminated an average of 2,539 cases a year, compared to 2,016 for the Southern District and 10,541 for all NND districts. The corresponding averages for the next five years are 4,509, 4,236, and 20,802 . In percentages the growth in terminations between the two periods is 77.6 percent for the Northern District, 110.1 percent for the Southern District, and 97.3 percent for all NND districts. Once again the Northern District has lagged.

Let us see who is doing the best job in controlling caseloads. The average number of pending cases grew (between the before and after periods) by 78.4 percent in the Northern District, 94.2 percent in the Southern District, and 39.5 percent in the circuit as a whole. The Northern District does better than the Southern in this comparison but much worse than the NND districts as a whole.

Table 3 refines the study by dividing the number of trials, terminations, and pending cases by the number of judges in the respective districts. The purpose is to correct for the single factor most likely to affect these numbers. The results, however, do not differ markedly from those in Table 2. Again there is a dramatic reduction in number of trials in the Northern District, but most of it is between 1977 and 1979, and since then the number has fallen even faster in the Southern District, though not at all in the NND districts as a whole.

In terminations per judge, the Northern District does better relative to the comparison districts than it did in Table 2: its terminations rose $\mathbf{5 3 . 5}$ percent between the before and after periods, compared to 64.1 percent for the Southern District and 55.8 percent for the NND districts. But in control of backlog the Northern District does about the same, relatively, as in Table 2: the number

22 In this comparison only, results for the Northern District have not been subtracted from results for all non-Northern districts, as I lack the data necessary for this adjustment. 


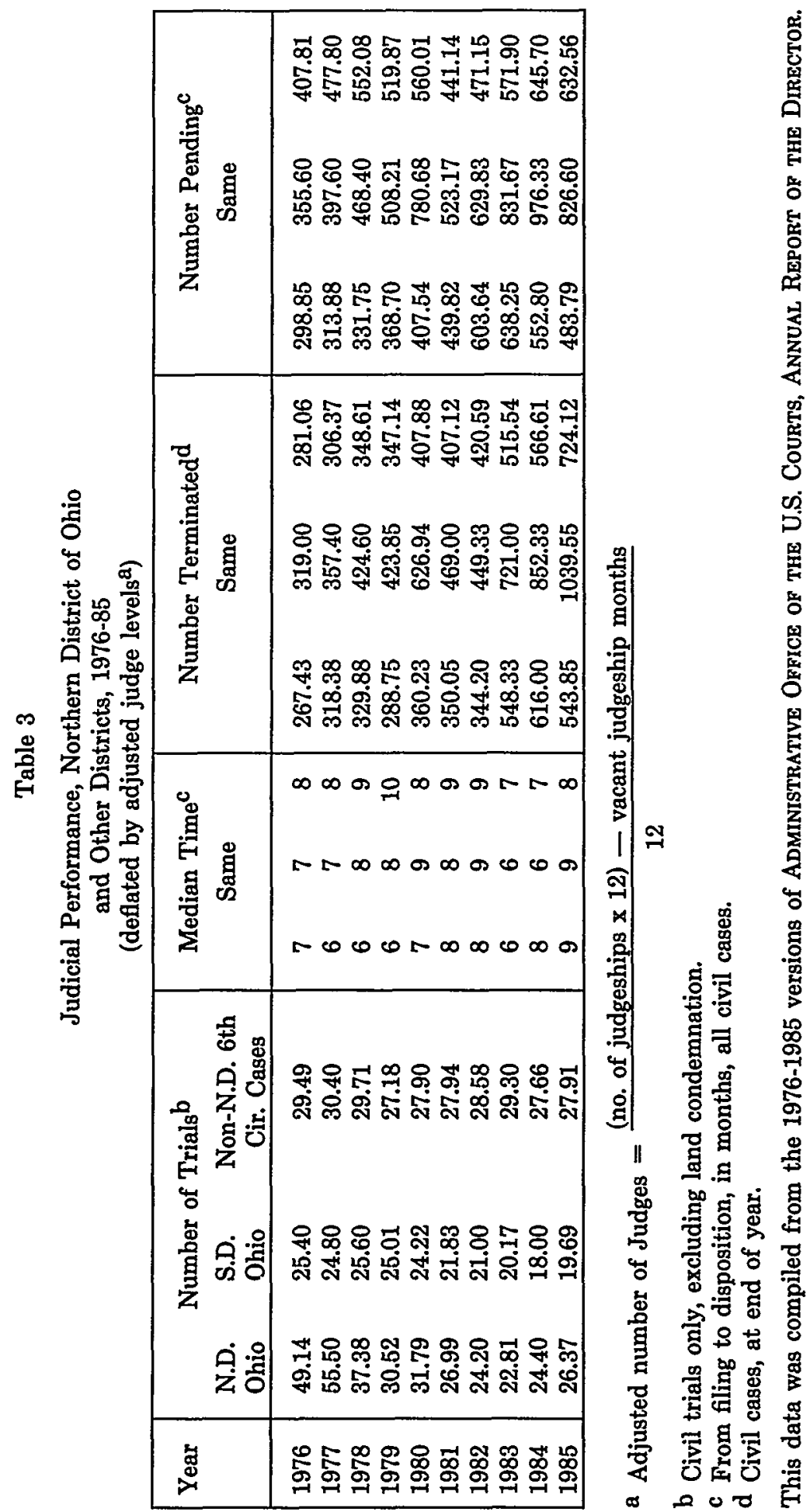


of pending cases in the Northern District rose 58 percent between the two periods, compared to 50.9 percent for the Southern District and 9.7 percent for the NND districts.

To summarize, the study does not support a conclusion that the summary jury trial increases judicial efficiency; but again the crudeness of the study must be stressed. It does not show that the summary jury trial is a failure but does highlight the uncertainty that must attend an experiment in judicial reform that is not conducted using scientific techniques that would enable the outcome of the experiment to be evaluated objectively.

The results of the study, assuming they hold up under more rigorous statistical analysis (which would attempt to control for additional factors besides number of judges that may affect judicial performance across districts), are not particularly surprising. For compared to what should the summary jury trial be expected to raise the settlement rate? Compared to utter judicial passivity? That would not be a realistic benchmark. The summary jury trial is one of many methods of encouraging settlements. Others include a lengthier pretrial conference and more active judicial involvement in the parties' settlement discussions. ${ }^{23}$ The judicial time taken up in summary jury trials might be spent equally well or even better on some other method of encouraging settlements, especially when one considers how lavish the summary jury trial is with the judge's time: he spends a whole day trying to settle one case.

We should keep in mind that settling more cases may make litigation more attractive to other disputants by reducing the waiting period for a trial. The total number of trials may not be affected, though the data in Table 2 suggest that the summary jury trial has not reduced the court queue. Another point is that the device operates on only a small fraction of the total number of trials, which in turn is only a small fraction of the total number of cases. Judge Lambros conducts a summary jury trial in any case that he thinks likely to require a jury trial of more than three days. However, most judges set a higher threshold, recognizing that a

${ }^{23}$ A recent survey found that most lawyers think that active judicial involvement in settlement negotiations is the key to raising the settlement rate. See WAYNE BrazI, SETtling Civil Suits: Litigators' Views About Appropriate Roles and Effective Techniques for Federal Judges (Am. Bar Ass'n 1985), summarized in Brazil, What Lawyers Want From Judges in the Settlement Arena, 106 F.R.D. 85 (1985). Professor Schuck's conference paper, supra note 9 , is a case study of such involvement. Admittedly that involvement was far more extensive than a summary jury trial would require; on the other hand the case was gigantic. 
summary jury trial lasting a day could substantially increase the total trial time for a case that fails to settle after the summary stage.

In 1985, according to Table C8 in the Annual Report of the Director of the Administrative Office of the U.S. Courts, of 20,729 trials conducted in federal district courts 2,249 (10.9 percent) were civil jury trials lasting at least four days. If summary jury trial reduced by 10 percent the number of lengthy civil jury trials, this would only be a one percent reduction in the number of trials. The reduction in the number of days of trial time would of course be greater but would be partially offset by the days devoted to the summary jury trial itself.

Table 4 tries to quantify the potential savings in trial time from using summary jury trials. It first calculates the total number of days that federal judges spend in civil or criminal trials from the data published by the Administrative Office, and then it assumes that (1) a summary jury trial is held in every civil jury trial that (today) lasts four or more days; (2) it lasts one day except when the actual trial lasts 30 days or more, in which event the average summary jury trial is assumed to last three days, to constitute an adequate microcosm of the full trial; and (3) for these very long cases, the settlement rate after summary jury trial is only twothirds the settlement rate in cases with short trials (e.g., if the assumed settlement rate for short trials were 90 percent, for long trials it would be 60 percent). The reason for (3) is that a case that (if tried) will require a very long trial is likely to be extremely complex, making it less likely that any new settlement device will succeed when all other settlement devices have failed. For it must be remembered that we are dealing with a class of cases that are in fact tried, though if summary jury trial were universal they might not be. Also, a long trial is more likely as the stakes in the case increase. In the settlement model, raising the stakes $(J)$ makes settlement less likely.

On the basis of these assumptions, which are arbitrary but plausible and not unfriendly to the summary jury trial, ${ }^{24}$ Table 4 shows that substantial time savings are obtained from making summary jury trial universal only if the percentage of cases settled by the device is very high, and even then the maximum savings in

34 For example, I have not excluded cases in which summary jury trial is used and fails to bring about a settlement, with the result that the case is tried. I assume that even some of these cases would be settled by use of the summary jury trial if the device were universal. 


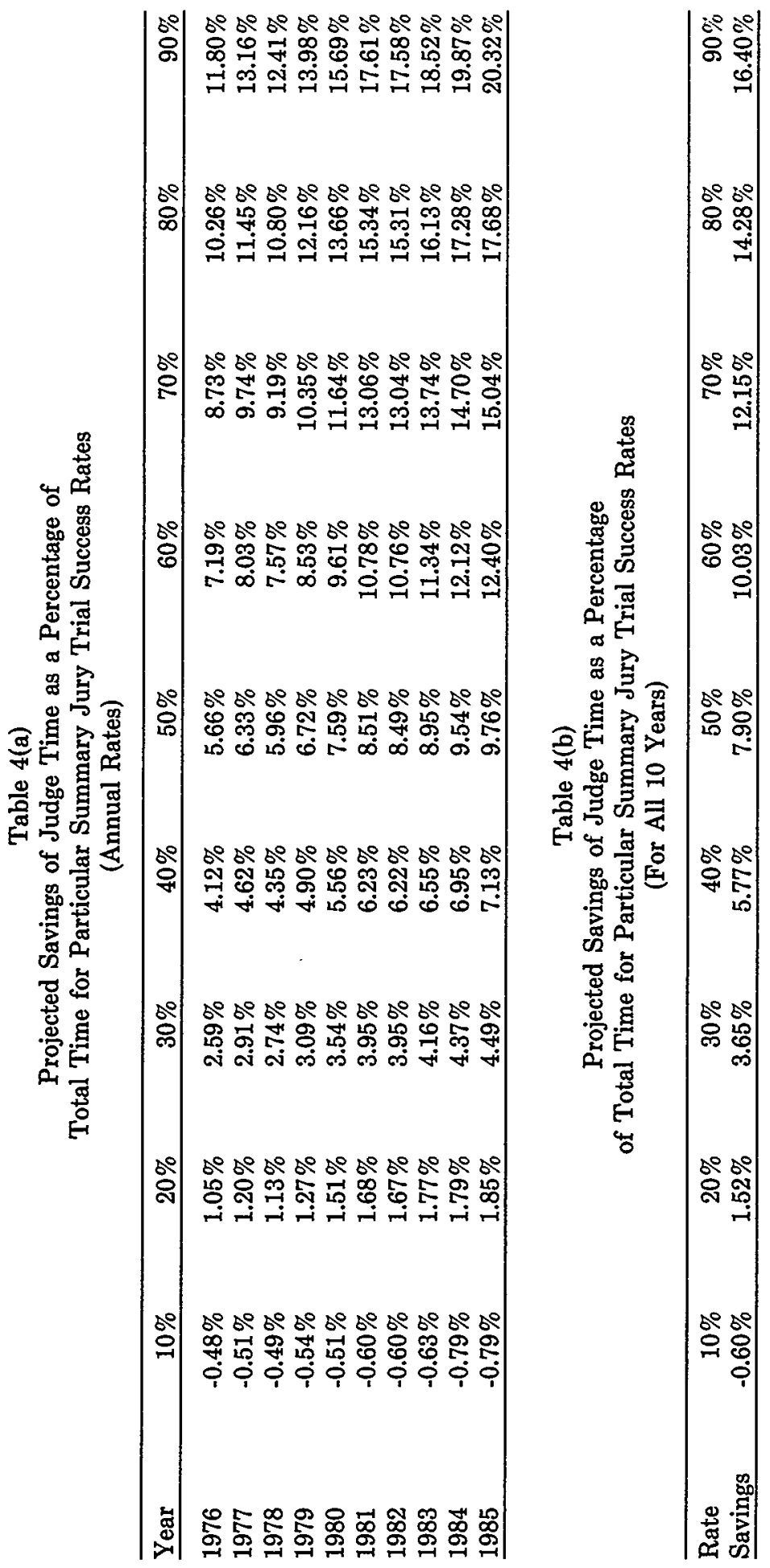


trial time is only 20 percent. ${ }^{25}$ But the percentage of settlements is unlikely to be very high, given that the universe is all those cases not settled by any device today. Although judges using summary jury trial report overwhelming success, they are not using the device all the time; they are using it in cases where they think it likely to work. If they used it in all cases bound for trial, the success rate would fall. Moreover, the only judges who use the device today are those who believe in it and want to make it work; nonbelievers forced to use it would have a lower success rate. This might not be true if every district judge were persuaded to use it voluntarily, but that is unlikely to happen.

3. Legal and Prudential Constraints. My third criterion is that any proposed alternative respect legal and prudential constraints on judicial power. Although Congress has empowered lower federal courts to issue supplementary rules of procedure, ${ }^{26} \mathrm{I}$ am not sure it has authorized them to order summary jury trials. Admittedly, federal judges have long had the power to convene advisory juries. But the summary jury is not an advisory jury. It does not advise the judge how to decide the case, but is used to push the parties to settle. It is therefore outside the scope of rule 39(c) of the Federal Rules of Civil Procedure, which deals with advisory juries. ${ }^{27}$

I also can find nothing in rule 16 (pretrial conference) to suggest that judges are authorized to convene juries to assist in settlement. It is true that rule $16(\mathrm{c})(7)$ permits the participants in the pretrial conference to "consider and take action with respect to ... the possibility of settlement or the use of extrajudicial procedures to resolve the dispute." But the Advisory Committee's note to the 1983 amendment which added this subsection does not mention summary jury trial or authorize any special procedures for encouraging settlement. All the subsection appears to require or authorize, so far as is relevant here, is the discussion (not implementation) at the pretrial conference of extrajudicial proce-

\footnotetext{
${ }^{25}$ The increase in the projected savings of trial time during the period of years in the table reflects the fact that trials have been getting longer.

28 See 28 U.S.C. \& 2071 (1982).

${ }^{27}$ Rule 39(c) allows the district court, "[i]n all actions not triable of right by a jury," to "try any issue with an advisory jury." This would seem to exclude the summary jury trial, which is used in actions triable of right by a jury. As the Advisory Committee's note explains, rule 39(c) codifies the traditional practice in equity, maritime law, and other nonjury fields whereby the judge could if he wanted convene a jury to advise him on questions of fact. See, e.g., Kohn v. McNulta, 147 U.S. 238, 240 (1893); In re Incident Aboard the D/B Ocean King, 758 F.2d 1063, 1071-72 (5th Cir. 1985); 9 C. Wright \& A. Miller, Federal Practice and Procedure § 2335 (1971).
} 
dures-which summary jury trial is not.

Of course not everything not expressly authorized by the federal rules is therefore forbidden to federal judges. But lack of clear authority is a reason for hesitation in sensitive areas. Summary jury trial is an enlargement of the use of the jury. Jury service is, as noted earlier, a form of conscription; and conscription is not popular in this country. Granted, if the summary jury trial is as effective a settlement device as its advocates believe, it will reduce the demand for jurors. But that is only a possibility, and in any event judges should be cautious about instituting new forms of involuntary servitude, mild as this one is. The fact that Congress appropriates money for jurors without indicating how they are to be used does not necessarily authorize novel forms of jury service. Nor does anything in the Jury Selection and Service Act of 1968, ${ }^{28}$ which governs the use of juries in federal courts, empower federal judges to summon jurors to serve as mediators.

An important issue is what the jury in a summary jury trial is told, and when. Some judges tell the jury at the outset that its verdict will only be advisory-which is likely to reduce the verdict's informational value; other judges tell the jury after it has rendered its verdict; some never tell it. ${ }^{29}$ Never telling the jury worries me. The jury, especially in commercial litigation, is a curious institution - a vestige, many believe, of a previous epoch in legal evolution. If it works at all, this may be because jurors are impressed by being told that they are exercising governmental power. That makes them act more responsibly than one might have thought likely given the nature of the selection process and the lack of incentives for jurors to perform well. (The same, by the way, can and should be said about judges.) If word got around that some jurors are being fooled into thinking they are deciding cases when they are not, it could undermine the jury system. ${ }^{30}$

Telling the jurors after they have delivered the summary verdict that the verdict is not legally binding is only a partial anodyne for my concern. (Telling them in advance eliminates the principal advantage of the summary jury trial over a mock proceeding,

${ }^{28} 28$ U.S.C. $\$ \S 1861-1877$ (1982).

28 See Recent Development-Procedure: Summary Jury Trials in United States District Court, Western District of Oklahoma, 37 OKLA. L. REv. 214, 217 n.16 (1984).

so Some social scientists believe, see, e.g., R. Hastie, S. Penrod \& N. Pennington, supra note 11 , ch. 3 , that they can get mock juries to perform pretty much as real ones do; and mock jurors know they are not exercising real power. But the social scientists have tools for selecting and motivating jurors that are denied to the court system; they have greater flexibility in selection and compensation. 
where the lawyers hire people off the street to be the jurors. Thus, advance notice calls in question the entire rationale of the device.) The jurors are still being fooled; and they are learning that juries sometimes make decisions and at other times simply referee fake trials. As word spreads, the conscientiousness of jurors could decline; it is almost a detail that the utility of the summary jury trial would also decline.

These reflections lead me to wonder, again, why we don't see proposals for summary bench trials. The answer may be that since the average bench trial in the federal system is only half the length of the average jury trial, ${ }^{31}$ the potential benefits of settlement are smaller.

There is some (though I think tenuous) basis for worrying that summary jury trials might coerce settlements by large corporate defendants. Suppose a corporation is sued for several million dollars and a summary jury trial results in a verdict of $\$ 10$ million. No longer can the corporation pretend that the lawsuit has no possible merit and that it exposes the corporation to no appreciable danger of financial loss. A verdict that is substantial relative to the firm's earnings or assets may be deemed material information that must be disclosed to the shareholders in order to avoid a charge of securities fraud. Such disclosure could be a costly sanction, and would put great pressure on the firm to settle rather than tough it out till the real trial, which may be many months later. In this setting the summary trial becomes the real trial rather than just an aid to settlement. It is a very cheap real trial and that is all to the good, but it may also be an unreliable method of adjudicating a substantial dispute.

I put little weight on this argument, however. If the stock market is efficient, as the evidence indicates, ${ }^{32}$ the market impact of disclosure of an adverse summary jury trial verdict will be buffered by awareness that the verdict may not accurately predict the results of a real trial. If it is a good predictor, disclosure will-as it should-affect the market's valuation of the firm.

4. Benefit to Society. My last criterion for a proposed alternative to the conventional trial is that it move us in the right direction. Supposing that with the summary jury trial a higher fraction of cases is settled (at this moment a highly uncertain prediction), is this a good thing from the standpoint of society as a

s1 See R. Posner, supra note 1, at 130 n.1.

s2 See, e.g., J. LorIE \& M. Hamilton, The Stock Market: Theories and Evidence ch. 4 (1973). 
whole? It benefits the parties to cases that would otherwise have been tried (at least if coerced settlement is not a serious problem), because settlement is cheaper than trial. But is it a good or a bad thing for the rest of society?

The object of policy, even narrowly conceived, is not to maximize the settlement rate; it is to minimize the total costs of the system of dispute resolution. These include costs of legal error as well as the direct costs, to the parties and the judicial system, of dispute resolution. ${ }^{33}$ Raising the settlement rate will reduce the direct costs, in the short run, because litigation is more costly than settlement. But in the long run the litigation rate may rise. With few suits being tried and therefore few decisions being made, parties will find it difficult to predict how courts will resolve their disputes. $P_{p}$ and $P_{d}$ in the formal model of settlement will increasingly diverge, and cases will be litigated that would be settled if parties had better information about how their cases would be decided if they went to trial. Raising the settlement rate may also, as suggested earlier, increase the number of cases filed, by lowering the expected cost of litigating (which includes settlement, the terminating event of most lawsuits); if so, the total costs of resolving disputes may rise even if the average cost falls because more cases are settled.

But actually the summary jury trial is unlikely to affect the settlement rate even if, as I have been assuming, it increases the probability of settling each and every case subjected to the device. Judges have only so much time to devote to civil trials, given the pressure of their other responsibilities, in particular the pressure that the Speedy Trial Act exerts to give priority to criminal trials. Faced as most federal district judges are with many more cases filed in a year (more than 500 in the busier districts) than they can try (perhaps 40 on average, of which almost half would be criminal cases), they must, to equilibrate supply and demand, delay trials, refer disputes to magistrates, and put pressure on the parties to settle. If the summary jury trial settles some cases that would otherwise be tried, other cases will advance in the queue; or the judge will put less pressure on the parties to those cases to settle; or

${ }^{33}$ This is a conventional economic formulation of the goal of procedure, see, e.g., Posner, An Economic Approach to Legal Procedure and Judicial Administration, 2 J. LEGaL STUD. 399, 401 (1973), and in a slightly different form was used by the Supreme Court in Mathews v. Eldridge, 424 U.S. 319, 335 (1976), as the test for whether specific procedures provide due process of law. 
fewer cases will be referred to magistrates. ${ }^{34}$ Whatever happens, there will be the same number of trials. The summary jury trial is a substitute not for real trials but for alternative methods of pushing the parties to settle, and it is a costly substitute.

Of course, for those who believe the federal courts are being underutilized, any procedure that has a fair chance of raising the settlement rate in these courts, thereby making room for new cases, will be welcome. That is not my view, though it would take me too far afield to show why the federal courts have too much rather than too little business; it is not the view of the advocates of summary jury trial, either. They accept, regretfully or resignedly, rather than welcome, the prospect of an ever-expanding federal caseload. They merely hope to process cases more rapidly by reducing the fraction of cases that are tried. They are like highway engineers, for whom the natural solution to highway congestion is to build more and wider highways. The advocates of more efficient machinery for expediting case flow have not shown equivalent interest in measures to reduce the overall demand for federal judicial services, as by raising the jurisdictional minimum amount in controversy in diversity cases, or raising filing fees above their present ridiculously low levels, or returning some legal responsibilities to state courts. It is in those directions, I believe, that the only lasting reforms lie. ${ }^{35}$ It is merely a detail that the summary jury trial, despite the enthusiasm it has generated, remains problematic even on its own rather too limited terms of reference.

\section{SOME Extensions of the ANALysis}

\section{A. Court-Annexed Arbitration}

My analytic framework can be applied to other alternatives to the conventional trial besides summary jury trials, and I want to mention two. One is "court-annexed arbitration," 38 which means forcing the parties to present their case to a private lawyer-arbitrator (sometimes a panel of arbitrators) before they can go to trial. As with the summary jury trial, the arbitrator's decision is not binding; the hope is that it will encourage settlement.

This device avoids the problems of using the jury as a settle-

s4 This is especially true since some proponents of the summary jury trial envisage that most of these trials will be conducted by magistrates rather than judges.

ss See R. PosNER, supra note 1, pts. II-III.

so $\mathrm{On}$ this and other proposals see the authorities cited supra at note 2; see also E. Lind \& J. Shepard, Evaluation of Court-Annexbd Arbitration in Three Federal DisTrict Courts (Fed. Judicial Center, Sept. 1983). 
ment aid. Since arbitrators are less representative of jurors than summary jurors are, it might seem obvious that arbitrators' decisions would produce less information about likely outcomes at trial, and hence fewer settlements, than a summary jury trial would do. But depending on the variance among juries, an arbitrator who is an experienced trial lawyer may render a decision more representative of what the average jury would come up with than the decision of any single jury. And of course the device is usable in bench as well as jury trials, as the summary jury trial is not.

The biggest objections to court-annexed arbitration involve expense and legality. The expense is apt to be greater than that of the summary jury trial for two reasons. First, although arbitration is less expensive than an ordinary federal trial, it is more expensive than the average settlement negotiation. It involves a trial, albeit to an arbitrator rather than a judge or jury. This means that witnesses must be prepared and examined and that lawyers must spend time in court, for which they usually charge higher fees than for out-of-court work. The summary jury trial is also a sort of trial, but no witnesses actually testify; and it is a last-ditch effort to settle a case that seems bound for trial, rather than a required step in every case. Court-annexed arbitration is ordered in every case that meets certain requirements as to amount in controversy, even though most of those cases would have been settled without courtannexed arbitration.

The cost savings from court-annexed arbitration are speculative. An example will show how the device could actually increase the cost of resolving legal disputes-and do so even if it is much cheaper than trial and even if all cases subjected to it settle after the arbitrator's decision. Suppose that without court-annexed arbitration 90 out of 100 cases filed would settle, at an average settlement cost of $\$ 1,000$ (not the amount of the settlement, but the expense of effecting settlement), and the other 10 would go to trial, at an average cost of $\$ 25,000$. With court-annexed arbitration, all settle, but at an average cost (the cost of the arbitration) of $\$ 5,000$. The total litigation and settlement costs without court-annexed arbitration are $\$ 340,000$, while the total costs with it (all settlement costs) are $\$ 500,000$. If 5 percent of the arbitrated cases are tried, which would be half the litigation rate without court-annexed arbitration, ${ }^{37}$ the total costs of court-annexed arbitration in my example rise from $\$ 500,000$ to $\$ 625,000$, which is almost twice the cost

37 Nejelski \& Zeldin, supra note 2, at 810, estimate that court-annexed arbitration in the Third Circuit has cut the litigation rate there by a little more than one half. 
without the device. This comparison is somewhat unfair because it ignores the cases that settle before the arbitration hearing; but even if most do, the total costs of dispute resolution may not be lower with court-annexed arbitration. If, for example, 60 percent of the cases settle before the arbitration hearing (at a settlement cost of $\$ 1,000$ per case), 35 percent are settled after the hearing, and 5 percent are tried, the total costs will be $\$ 385,000$, which again exceeds (though by a smaller margin) the total costs without courtannexed arbitration $(\$ 340,000)$.

The problem of legality is twofold. First, if a party to courtannexed arbitration refuses to settle after arbitration, and then does worse at trial, he must pay the arbitrator's fee, which will usually be several hundred dollars. In effect this is a fee for demanding a trial. But Congress has set no such fee.

Second, court-annexed arbitration effectively increases the statutory minimum amount in controversy. Such arbitration usually is compulsory only for claims that do not exceed a specified monetary value, most commonly $\$ 100,000$. The thinking behind the limit is that with modest claims the parties will not think it worthwhile to incur the costs of two procedures-the arbitration, and then the trial-while with larger claims the parties are unlikely to accept the arbitration as binding. Apparently the combination of having to pay the arbitrator's fee if you reject his award and of having to pay the usual trial expenses for both the arbitration and the trial is a potent disincentive to insisting on a trial of a modest claim in districts that have court-annexed arbitration.

This seems an indirect method of increasing the minimum amount in controversy requirement in the federal courts from zero for virtually all federal claims, and from $\$ 10,000$ for claims founded on diversity, to wherever the cut-off point for court-annexed arbitration is fixed. This cuts against the grain of Congress's decision, wise or not, to make federal courts accessible to smaller claims.

Although I have reservations about court-annexed arbitration, I am pleased to note that the Private Adjudication Center of Duke Law School, which operates a court-annexed arbitration program for the Middle District of North Carolina, is using random assignment in order to enable a rigorous statistical evaluation of the program, ${ }^{38}$ and I am told that random assignment will also be used in the District of New Jersey and the Eastern District of New York.

ss See Duke's Private Adjudication Center, DukE's L. MAG., Summer 1985, at 27, 30. 


\section{B. Private "ADR"}

The other proposal I shall touch on, much too briefly, is the proposal to encourage voluntary alternative dispute resolution by commercial services, often offered by law firms. It is not obvious why this needs government encouragement, but an argument can be made, along the lines suggested earlier, that if settlement confers external benefits the government should subsidize the settlement process.

A practical problem, and perhaps one that will come to haunt court-annexed arbitration also, is that private attorneys may dislike submitting their disputes to other private attorneys, who in the nature of things are potential competitors for their clients. The client may wonder why he is hiring a lawyer to argue before another lawyer, rather than hiring the second lawyer directly to receive authoritative legal advice.

Private "ADR," being voluntary, is much less problematic than either the summary jury trial or court-annexed arbitration. And it consumes no judicial resources (or very few-occasionally, as with ordinary arbitration, judicial enforcement of the arbitration award may be sought). I wish it all the best, though I think its potential is limited, if only because, as suggested earlier, it is not clear whether the overall settlement rate can actually be raised.

\section{ConcLusion}

The three proposals discussed in this paper have much in common. They seek to induce more settlements, and to do so by generating more information about the likely outcome at trial. They thus recognize implicitly both that litigants generally behave rationally and that, given current judicial caseloads, a higher settlement rate would benefit litigants in general and not just the parties to the settlement. I am sympathetic to both propositions (especially the first), but as already suggested by the analogy of highway construction I am not persuaded that making settlement cheaper to the parties is the solution to the caseload crisis. I would prefer to make the parties bear a larger fraction of the total costs of trial, including the queueing costs that trials impose on other parties. A recent study found that the average out-of-pocket cost to the federal government of certain tort cases tried by jury is $\$ 15,028$-and this excludes the queueing costs. ${ }^{39}$ But the fee for

so See J. Kakalik \& A. Robyn, Costs of the Crvil Justice System: Court Expenditures for Processing Tort Cases zviii, zix (Rand Inst. for Civ. Justice 1982). 
filing a case in federal district court is only $\$ 60$.

More realistic filing fees would be a simpler as well as more efficacious method of dealing with the caseload crisis than new ways of inducing people to settle lawsuits before trial. A point might be reached where it could be argued that filing fees for federal jury trials were so high as to impair civil litigants' rights under the Seventh Amendment, but it would not be much of an argument so long as the fees did not exceed a reasonable estimate of the social costs of such trials. Although court-annexed arbitration has the effect of increasing the filing fees for small claims, it does so in rather a sneaky fashion.

Even more important than the issue of the soundness of the proposals discussed in this paper is the question whether judicial administration should be an art or a science. More precisely, should it remain exclusively an art, practiced by judges and judicial administrators, or should it also have the elements of a science, practiced by economists, statisticians, and other social scientists? There is both a practical literature on judicial administration and a theoretical literature illustrated by the present paper, but the practical approach greatly predominates, and few policy changes in the area of judicial administration have reflected the findings of social scientists.

The imbalance seems to me unfortunate. Beginning with the promulgation of the Federal Rules of Civil Procedure in 1938 and accelerating with the caseload explosion that began around 1960, the federal courts have been an arena of massive experimentation in judicial administration. The milestones include liberalized class actions, one-way attorney's fee shifting, expansive pretrial discovery, managerial judging, the six-person jury, limited publication of appellate opinions, greater use of judicial adjuncts, and now "alternative dispute resolution," illustrated by the summary jury trial and court-annexed arbitration. Very few of these experiments have been conceived or evaluated in a scientific spirit and this may help explain why the federal courts remain in a state of crisis. Maybe a dose of social science is the thing, or one of the things, that the system needs. 